ARTICLE

\title{
Community Interest and the International Public Legal Order
}

\section{Sarah Thin ${ }^{1}$}

Accepted: 1 April 2021 / Published online: 19 April 2021

(c) The Author(s) 2021

\begin{abstract}
Traditional ideas about the private nature of the international legal order are increasingly being forced to contend with the development of public legal elements at the international level. The notion of the international community interest is key to understanding these developments and, as such, has transformed our understanding of international law. There are many different approaches to the public/private distinction in law, broadly categorised into relational, public authority, and interestbased approaches. These can be reduced to four key elements of publicness: the existence of a community or public; the universality of the public regime in question with its own boundaries; normative and institutional hierarchies; the objectivity of obligation and responsibility. The development of the community interest and related norms of international law can be seen to have introduced and strengthened all of these elements of publicness within the international legal system. It is thus on its way to becoming an international public legal order. This has important implications for our understanding of international law and the future development of the international legal order.
\end{abstract}

Keywords Community interest · International public law · International public interest · International community $\cdot$ Public authority · International legal system

\section{Introduction}

The notion of the international community interest has transformed our understanding of international law. Where once international law was understood to concern itself exclusively with the protection of individual state interests through mirrorimage bilateral relationships, now there are rules protecting 'global public goods',

\footnotetext{
1 See Bodansky (2012).
}

Sarah Thin

sarah.thin@maastrichtuniversity.nl

1 PhD Candidate, Maastricht University, Maastricht, The Netherlands 
such as the global environment, and 'universal values', ${ }^{2}$ including that of human dignity. There are even public-law style limitations on the contractual freedom of states to make international agreements, ${ }^{3}$ and a form of public-interest litigation through the invocation of responsibility for the breach of erga omnes obligations. ${ }^{4}$

International law has traditionally been likened to private law, ${ }^{5}$ but these community-interest-oriented developments seem to suggest a shift from this private-law type system towards a more public legal order. The shift towards a public-law narrative can be seen as an attempt to explain and theorise these changes. From global constitutionalists, ${ }^{6}$ through global governance, ${ }^{7}$ and global administrative law, ${ }^{8}$ the literature is strewn with attempts to recast (aspects of) public international law as a form of 'international public law'. ${ }^{9}$ Despite the wealth of scholarship discussing and analysing this shift, relatively little has been written on the role of community interest per se within this evolution. Despite Simma's comment that the incorporation of the community interest has meant that international law "begins to display more and more features which do not fit into the "civilist", bilateralist structure of the traditional law [...] it is on its way to being a true public international law, ${ }^{10}$ the impact of community interest on a conceptual level remains underexplored. This article puts community interest at the centre of this analysis and argues that it is key to understanding the shift towards publicness in international law.

Furthermore, this contribution develops a new approach for analysing the notion of publicness in international law. Existing understandings of the divide between public and private have thus far hindered a fuller understanding of this dynamic at the international level. Formalist approaches to this distinction that are developed at the domestic level do not account for the myriad essential differences between a national and international legal order. In response to this problem, this article analyses a variety of different approaches to the public/private distinction in order to draw out the key elements that transcend the difficulties inherent with comparing such different legal orders. This provides the basis for analysis of the impact of the community interest on the nature of the international legal order.

The article begins by examining and categorising a wide variety of approaches to the public/private divide in domestic legal theory, drawing out four key elements of publicness that are common to all sets of approaches (Sect. 2). The following section

\footnotetext{
2 Dupuy (2005). Art. 53. II, Part Two, and UN Doc. A/56/10, Art. 48.

5 Schwöbel (2012), pp. 1111-1112.

6 E.g. De Wet (2006); Peters (2006).

7 E.g. Donaldson and Kingsbury (2013); Goldmann (2016); Krisch (2012).

8 Kingsbury and Donaldson (2011b).

9 Von Bogdandy et al. (2016), p. 1.

10 Simma (2009), p. 268.
}

3 In the form of jus cogens norms: Vienna Convention on the Law of Treaties (1969), 1155 UNTS 332,

${ }^{4}$ See Barcelona Traction, Light and Power Company, Limited (Belgium v. Spain), Judgment, ICJ Reports 1970, p. 3, paras. 33-34 and International Law Commission (ILC), Draft Articles on Responsibility of States for Internationally Wrongful Acts, with Commentaries (2001), ILC Yearbook 2001, vol. 
(Sect. 3) applies these elements to the international legal order. It demonstrates the ways in which the legal notion of community interest has had a foundational role in the development of fledgling structures of an international public law. Section 4 reflects on the implications of this categorisation of the international legal order as 'public'. It argues that, far from being a purely descriptive or abstract academic exercise, the determination of the public nature of the international legal system has important consequences for its functioning and future development. The final section will offer some concluding remarks.

\section{Elements of Publicness}

The distinction between public and private has a long pedigree. From Roman law concepts of jus publicum and jus privatum, ${ }^{11}$ it has evolved to form an important part of the structure of modern domestic legal systems. ${ }^{12}$ When it comes to the international sphere, however, the picture is more complicated. Many of the traditional structures and machinery of state, including forms of the separation of power and the existence of the three branches of government (legislative, executive, judicial) are largely absent at the international level. This section sets out to determine the key elements that illustrate a turn towards publicness in a legal system so as to be able to apply them to the international level. It begins by considering the range of different theoretical approaches that have been applied to the public/private divide in the domestic law context, before drawing out the key aspects that will form the framework for analysis of the international legal order.

\subsection{Theoretical Approaches to the Public/Private Divide}

The myriad different approaches to the distinction between public and private law can be grouped into three main categories, labelled here as 'relational', 'authorityor function-based', and 'interest-based' approaches. Each takes a different starting point or focus as the basis of analysis of the public/private divide. Nevertheless, as will be shown further below, all share certain key elements that reflect the essence of the difference between public and private.

\subsubsection{Relational Approaches}

The first category of approaches is comprised of those which focus on the legal relationship created by a particular rule. Some such approaches concentrate on the identity of the parties to the legal relationship. This is a particularly common method by which to differentiate between public and private law. ${ }^{13}$ In essence, it is posited that

\footnotetext{
11 Ciongaru (2014), p. 112; Mates and Barton (2011), p. 182.

12 Loughlin (1992), pp. 1-2.

13 Kelsen (1949), p. 201. See also Holland (1916), p. 128; Willoughby (1924), p. 37. See also Kelsen (2009).
} 
that while public law is 'the law regulating relations between institutions of government and its subjects', private law is 'the law regulating relationships between subjects'. ${ }^{14}$ As such, rules regulating income tax, for example, fall within public law, whereas a contract of sale between two individuals amounts to private law. The simplicity of this distinction is undermined by the difficulties associated with the characterisation of actors as public or private. ${ }^{15}$ Certain developments in modern society have blurred these lines, notably the practice of governments contracting out public services to private companies. ${ }^{16}$

A slightly more nuanced version of this approach focuses on the nature or structure of the legal relationship itself rather than the identity or classification of the parties involved. The private/public distinction is often conceptualised in terms of relationships of equality, on the one hand, and 'superiority' and 'inferiority', on the other. ${ }^{17}$ In private-law-regulated relationships, the parties are understood as being 'equal', whereas public law regulates those relationships in which there is a legally inferior and a legally superior party. ${ }^{18}$ This is similarly expressed in the language of 'horizontal' and 'vertical'. ${ }^{19}$ Under this terminology, vertical relationships (which would traditionally be those between the state and subjects) are regulated by public law, whereas horizontal relationships (traditionally between individual subjects) are regulated by private law. ${ }^{20}$

This 'inferiority'-'superiority' dynamic can also be seen as a question of consent at the stage of formation of the rule. Kelsen contrasts what he terms 'the principle of autonomy' and 'the principle of heteronomy'. ${ }^{21}$ According to this perspective, legal relationships which are formed in accordance with the principle of autonomy create obligations which 'do not come into existence against or without the will of the individual to be obligated'. ${ }^{22}$ The obvious example would be the case of a contract. The formation of obligation is directly consensual. Such relationships are governed by private law. On the other hand, in a public law relationship, the obligation is dictated by the state. The public actor (state organ or representative) 'may be considered as superior to the private person, not because the organ represents the state, but because it is empowered to obligate the private person by one-sided declarations of will'. ${ }^{23}$ Inevitably these versions of the relational approach end up encountering the same problems as those mentioned above, since the identification of horizontal or vertical relationships inevitably harks back to the identification of the actors involved as public or private. This circularity is unfortunate but has not prevented

\footnotetext{
14 Loughlin (2013), p. 11.

15 Kelsen (1949), p. 202; Ciongaru (2014), p. 113.

16 See e.g. Oliver (2004); Bamforth (1999).

17 Kelsen (1949), pp. 203-204.

18 Ibid., p. 203.

19 See e.g. Knox (2008).

20 Ibid.

21 Kelsen (1949), pp. 204-205.

22 Ibid., p. 204.

23 Ibid., p. 205.
} 
this from being a popular approach to the definition of publicness. ${ }^{24}$ It is avoided for the most part by the next category of approaches by focusing on the actual functions that are played by public law and public actors.

\subsubsection{Authority/Function-Based Approaches}

This second category focuses on the functions of public law and the systemic legal authority that underpins them. This is premised upon the idea that there are certain functions of law that are inherently public in nature. ${ }^{25}$ What is considered a "public function' differs greatly across polities. ${ }^{26}$ For some, health or education provision is a public function, for others it is not. Despite this, there are certain key legal functions that can only be provided by a public organisation. These relate to the law which governs, in a broad sense, how laws are made, how they are implemented, and how legal disputes are adjudicated.

These functions are public primarily because they necessitate public authority. ${ }^{27}$ Law creation relies on the legal sovereignty of public institutions to prescribe rules of conduct for the whole community; an expression of 'an absolute authority of rule exercised through the deployment of public power'. ${ }^{28}$ Law implementation and enforcement are also fundamentally public prerogatives. In contrast to private structures of law, where it is up to each subject to 'look after their own' to enforce their rights and exercise their legal faculties, ${ }^{29}$ public legal structures centralise and generalise this authority in the interest of the community. ${ }^{30}$ Finally, the power of adjudication (as opposed to that of private arbitration) is inherently public. A public adjudicator has the authority to pronounce upon the determination of rights and obligations of others; 'to exercise binding judgment over parties to a dispute concerning rights. ${ }^{31}$ As such, the role of courts is a key distinguishing feature between legal orders which operate within a public legal system and those which do not, i.e. purely private-law systems. ${ }^{32}$

These approaches are not focused on individual rules and relationships, but rather on the nature of the legal system. ${ }^{33}$ Public law both generates and limits public authority. ${ }^{34}$ It sets the contours of the system - as such, private law exists and operates within public law, rather than in opposition to it. ${ }^{35}$ It is premised upon a certain degree of legal organisation; the ability 'to envision the various legal norms as

\footnotetext{
24 See e.g. ibid., p. 201; Holland (1916), p. 128; Willoughby (1924), p. 37.

25 Tierney (2013), pp. 152-153; Loughlin (2004), p. 153.

${ }^{26}$ Loughlin (2004), p. 154.

27 Loughlin (2013), p. 13.

28 Loughlin (2004), p. 159.

29 Simma (1994), p. 230.

30 Kelsen (1949), p. 206.

31 Mulholland (1993), p. 117.

32 Ibid., pp. 130 et seq.

33 On systems, see generally Benvenisti (2008).

34 Tierney (2013), p. 155.

35 Mulholland (1993), p. 113.
} 
arranged within a hierarchy, composing together a coherent, logical order, ${ }^{36}$ with a central point of public authority. ${ }^{37}$

The third and final category of approaches steps back from this more formalist or theoretical perspective to view legal rules and areas of law in terms of the interests that they serve, rather than their systemic functions.

\subsubsection{Interest-Based Approaches}

This final set of approaches focuses on the distinction between public and private interest. This is also a very common approach, with ancient roots. ${ }^{38}$ The essential idea is that a law whose focus is the public interest is representative of public law, whereas a law which protects private interests belongs in the corpus of private law.

The main difficulty here lies in the definition of the two interests, and the assumption that public and private interest 'refer to two distinct kinds of interests which can be compared and contrasted'. ${ }^{39}$ Some see the public interest as being the sumtotal or lowest common denominator of the individual interests of all members of a political community. ${ }^{40}$ This, however, is problematic. It 'eliminate[s] by definition the only truly serious case-the case where a particular interest is taken to be in the public interest but is not held by an individual or individuals in the society'. ${ }^{4}$ Society is made up of many different groups with remarkably different interests. It is not hard to conceive of a situation in which a law or policy (such as land reform or wealth redistribution) could be seen as being in the public interest, but contrary to the individual interests of certain people (in this example, wealthy or landowning classes). As Mates and Barton observe, 'If the public interest were completely identical to the sum of individual interests, it would not be necessary to formulate and discuss it as a specific category or specific concept ${ }^{, 42}$ This conceptualization of the public interest, therefore, would seem to be unworkable, or at least devoid of any real purpose.

A more logical approach characterises the public interest as a common interest, in contrast to private, individual interests. The distinction between individual interests and common interests is sometimes misunderstood as relating simply to the number of holders of the interest, i.e., singular or plural. In fact, the two categories of interest are 'qualitatively different'. ${ }^{43}$ While 'individual interests' are private interests, ${ }^{44}$ 'common interests' are those which are (a) shared by a group of actors and which

\footnotetext{
36 Benvenisti (2008), p. 393.

37 Kelsen (1949), p. 201.

38 Mates and Barton (2011), p. 182. See also e.g. Weill and Terré (1979), p. 70; Demichel and Laumière (1974), p. 13. See for further references Mates and Barton (2011), p. 182.

${ }^{39}$ Cassinelli (1958), p. 54.

40 Ibid., pp. 50, 54.

41 Zarecor (1959), p. 279.

42 Mates and Barton (2011), p. 181. See also Sorauf (1957), pp. 637-638.

43 Mates and Barton (2011), p. 181.

${ }^{44}$ Held (1970), pp. 18-19.
} 
(b) transcend the individual interests of those actors. ${ }^{45}$ They are therefore greater than the sum of individual interests of the members of the group in question, and instead present a quality of commonality that goes beyond the mere coincidental lining up of individual interests. ${ }^{46}$ In this sense, the public interest is the interest of the political community itself, as opposed to some sort of configuration of the individual interests of its members. It is to a great extent a construction, whether political, social, or legal; a fiction to which interests are imputed.

Even with such a definition it remains difficult to apply this approach when many rules and areas of law are full of overlapping private and public interests. Indeed, the public interest is given legal force in many areas of law that are "traditionally classified under the sphere of private law'. ${ }^{47}$ A commonly cited example is the protection of the weaker party in contract law. ${ }^{48}$ In practice therefore, drawing a clear dividing line between public and private would thus often appear to be arbitrary and artificial. It would seem that, rather than providing a clear distinction between public and private law, the interest-based approach is best suited to presenting publicness and privateness in terms of degree; a spectrum. The interest-based approach will thus often be one of relative 'priority', ${ }^{49}$ rather than a clear-cut categorisation of rules or legal systems.

\subsection{From Public Law to Publicness: The Elements of Publicness}

The preceding sections have demonstrated how complex the question of distinction between public and private can be. To add to this complexity, most ideas of publicness are tightly entwined with the legal and political setting of the nation state. ${ }^{50}$ They are therefore oftentimes difficult to apply outside that context. It is, however, possible to draw out key aspects of these approaches that are more easily transferrable. Rather than a clear-cut distinction between public and private, these may be conceptualised as elements of publicness that demonstrate and illustrate a tendency towards a public legal order.

The first and most fundamental such element is the existence of a political community: a public. ${ }^{51}$ This is central to the idea of publicness: publicness and particularly public law can be seen as the legal expression of the political community. ${ }^{52}$ In their own way, each of the approaches above relies on this element. Relational approaches are premised upon the difference between a legal relationship between subjects and the relationship between a subject and the state-and what is the state

\footnotetext{
45 Kingsbury and Donaldson (2011a), p. 81.

46 King et al. (2010), p. 957.

47 Mates and Barton (2011), pp. 182-183.

48 Ibid., p. 183.

49 Mulholland (1993), p. 141.

50 Palombella (2013), p. 286; Ciongaru (2014), p. 112; Peters (2006), p. 581; Tierney (2013), pp. 152153.

51 Palombella (2013), especially pp. 286-288.

52 Ibid., pp. 287-288.
} 
in this equation if not the legal manifestation or representative of the political community ${ }^{53}$ Functional and public-authority-based approaches also assume the existence of a political community. The notion of public authority and the system within which it exists are essential to defining and determining the boundaries of the political community within which they operate. ${ }^{54}$ Interest-based approaches are premised upon the distinction between, on the one hand, individual interests, and on the other, the interest of the particular political community: the public. ${ }^{55}$ As such, all approaches to the public/private divide are inevitably founded upon some idea of the political community expressed through the public.

The other main elements relate in one way or another to this political community. One element which is easily overlooked in domestic systems but which is still fundamental is that of universality. The 'public' authority in question must be generally valid within the boundaries of the community in question. ${ }^{56}$ This is an important aspect of the notion of a legal system - that it amounts to a single, coherent whole. ${ }^{57}$ This is particularly apparent in the authority/function-based approaches, ${ }^{58}$ but is also relevant in the characterisation of public actors in the relational approaches and the commonality of the public interest in interest-based approaches. ${ }^{59}$

Next, publicness implies a certain hierarchy (or hierarchies). ${ }^{60}$ This follows from the idea that the legal expression of the community incorporates interests and functions separate from that of its members. This reflects the superior/inferior idea in the context of relational approaches above. ${ }^{61}$ It is also visible in relation to public interest: the interest of the community must, at times, come into opposition with private interests, and may indeed trump them. ${ }^{62}$ As such, this implies the existence of a normative hierarchy (or at least normative differentiation) on the basis of the public interest.

Finally, the publicness of a legal system entails the objectivity of obligations and responsibility. ${ }^{63}$ To recall the discussion of authority/function-based approaches, the existence of a public system of law creation, implementation, and adjudication changes how the notions of obligation and responsibility are understood, and the link between the two. ${ }^{64}$ Where legal compliance is dealt with on a private-law basis, it remains a matter primarily if not exclusively between private, individual subjects. ${ }^{65}$

\footnotetext{
53 Loughlin (2013), p. 11.

54 Loughlin (2004), p. 154; Mulholland (1993), p. 113.

55 Cassinelli (1958), pp. 50, 54; cf. Zarecor (1959), p. 279.

56 Loughlin notably underlines the 'absolute' nature of public authority which would logically presuppose this universality: Loughlin (2004), p. 159.

57 Benvenisti (2008), p. 393.

58 Loughlin (2004), p. 159; Kelsen (1949), p. 206.

59 See e.g. Ciongaru (2014), p. 113 and Zarecor (1959), p. 279.

60 Schwöbel (2012), p. 1122.

61 Kelsen (1949), pp. 203-204.

62 Zarecor (1959), p. 279.

63 See Simma (1994), p. 230.

64 Mulholland (1993), p. 120.

65 See Shelton (2009), p. 557; Krisch (2012), p. 980; von Bogdandy and Venzke (2014), p. 3.
} 
Legal obligation and responsibility exist as between these subjects; they are thus essentially relative, or subjective. ${ }^{66}$ However, when legal compliance is incorporated into a public system, it is a matter for the whole community-whether because the public interest is engaged or because of a direct legal relationship to a public actor. ${ }^{67}$ It is thus objectivized.

These elements of publicness find expression in all the different approaches discussed above. Relational, function- or authority-based, and interest-based approaches all rest upon the underlying idea of the 'public'. In this form as a noun, the word encompasses the concept of a political and legal community that is the centre of the notion of publicness and public law. Universality, hierarchy, and the objectivity of obligation and responsibility all stem from this and are all reflected in their own way in the variety of approaches to publicness. Unlike those approaches, however, these four elements are flexible enough to be applied to a legal order that is inherently different in nature: the international legal order.

\section{Community Interest and the Public World Order}

As was noted above, the international legal order has experienced a number of important changes in recent decades. From the development of ideas of global shared values to the introduction of legal elements protecting those values, such as obligations erga omnes and peremptory norms, these new facets of the international legal system can be understood within the concept of community interest. It is through this concept that the elements of publicness explored above can be applied to the international legal order.

The international legal order differs from the domestic legal order in many ways, some of which will be explored in more depth further below. In international law there are no clearly defined institutional structures; no clear outer geographical boundaries marking the perimeter of the legal order; the main subjects of the legal order (i.e., states) are not only equally sovereign, at least formally, but also legal constructs themselves. The approaches discussed above have generally been developed at the domestic level, and as such they rely on or at least assume the presence of such pre-existing structures and concepts as 'government', 'state borders', 'population' or 'citizenry', and similar. The absence of such precepts creates a barrier to their application at the international level.

Focusing on the four elements of publicness elaborated above rather than a strictly defined distinction between public and private allows for the transcendence of the difficulties inherent in applying a strictly defined public/private distinction developed at the domestic level to the international sphere. Accordingly, this section turns to the community interest and its impact on international law in order to determine and demonstrate its role in the developing publicness of international law.

\footnotetext{
66 Paulus (2011), p. 122; Simma (1994), p. 230; Verdross (1964), p. 126.

67 See generally von Bogdandy and Venzke (2014); Mulholland (1993), pp. 130 et seq.; Shelton (2009), p. 564.
} 
First, however, some clarifications are necessary. The first half of this section therefore defines and explains the concept of community interest, while the latter focuses on the part played by community interest in developing an international public legal order.

\subsection{Defining the Community Interest}

Community interest is a term used frequently yet defined rarely. It is commonly invoked, sometimes apparently for purely rhetorical purposes, ${ }^{68}$ but at times seemingly as a more legalistic designation. ${ }^{69}$ This section seeks to define this concept by focusing in turn on two key aspects: what is meant by 'interest', and who, or what, is the international community.

\subsubsection{Interest}

An interest may be defined as the 'advantage or benefit of a person or group'; a 'stake or involvement in an undertaking' ${ }^{70}$ Interests therefore exist only in relation to the subject to whom this benefit or advantage would accrue. Herein lies the main distinction between interests and values: while interests are inherently dependent on the actor or holder to whom they accrue, values exist independently of those who believe in them-although, certainly, one may have an interest in their protection or promotion. ${ }^{71}$ The distinction between individual and common interests was discussed above. The community interest, like the public interest, reflects a common interest - in this case, the interest of the international community.

Not all interests are protected by law: non-legal interests should be distinguished from legal interests, such that only the latter benefit from legal protection. ${ }^{72}$ This was affirmed by the International Court of Justice (ICJ) in the South West Africa cases when it stressed that 'the existence of an "interest" does not of itself entail that this interest is specifically juridical in character'. ${ }^{73}$ There must be something more: 'in order to generate legal rights and obligations, [an interest] must be given juridical expression and be clothed in legal form'. ${ }^{74}$ An interest thus has no intrinsic legal force: to have legal effect, it must be granted such effect by a legal rule. ${ }^{75}$

Legal rules protect or promote the community interest in two main ways. A legal rule may protect a particular interest coincidentally, in the sense that it does not protect the community interest per se, but rather the things in which the community

\footnotetext{
68 See e.g. UNEP, 'Press Release: World Cities Day', 31 October 2019, https://www.unenvironment.org/ events/un-day/world-cities-day (accessed 14 December 2020).

69 E.g. Barcelona Traction (n. 4), paras. 33-34; Villalpando (2010).

70 Oxford English Dictionary, https://en.oxforddictionaries.com/definition/interest (accessed 16 December 2020).

71 Besson (2018), p. 38; Gaja (2013), p. 20.

72 Gaja (2013), p. 21; De Hoogh (1995), p. 12.

73 South West Africa, Second Phase, Judgment, ICJ Report 1966, p. 6, para. 50.

74 Ibid., para. 51.

75 Ibid., para. 51.
} 
may have an interest. This is the case with certain primary rules of international law, i.e., rules requiring certain standards of conduct, ${ }^{76}$ such as those that protect human rights or the environment. The distinction here is that these rules and the associated protections remain, even if the community interest as a concept were to evolve so as to no longer cover such subjects. In other words, the legal protections do not exist purely due to the community interest in their effects.

A different kind of legal rule grants legal force to the concept of the community interest itself. This is where the real transformative potential of community interest lies: at the intersection between community interest and the secondary rules of international law. Rules of jus cogens and obligations erga omnes in particular represent the most commonly accepted 'doctrinal expressions' of community interest. ${ }^{77}$ Both are considered to belong to the same overarching idea: namely, the heightened protection of fundamental community interests. ${ }^{78}$ These relate thus not to particular community interests, but to the concept of community interest itself.

As important as the potential of community interest may be, the notion of interest, as noted above, depends upon there being a holder of that interest. Unlike values, an interest does not exist independently of the person or group to whom it belongs. As such, it is necessary to determine what is meant by the 'international community' in this context.

\subsubsection{The international community}

The term 'international community' appears in such a diversity of guises and contexts that it can appear to mean both everything and nothing simultaneously. It is clear that there are occasions on which the term is used purely rhetorically. ${ }^{79}$ However, on other occasions, 'international community' (occasionally 'international community of states ${ }^{80}$ or 'community of nations ${ }^{81}$ ) carries a distinct meaning and is reserved to those actors with law-making authority on the level of states. This is particularly the case, for example, with the use of the term 'international community of states as a whole' in the context of the recognition of jus cogens norms. ${ }^{82}$ Despite the great influence that other actors may have in international law, ${ }^{83}$ states remain

\footnotetext{
76 I.e. rules requiring certain standards of conduct, as opposed to secondary rules (rules determining the formation, implementation, and operation of other rules): see Hart (2012), p. 117.

77 Simma (1994), p. 285.

78 Villalpando (2005), p. 84. See also Ménard (2010), p. 449; ILC, Draft Articles on Responsibility of States for Internationally Wrongful Acts, with Commentaries, Commentary to Art. 45, para. 4; Gowlland-Debbas (1996).

79 See e.g. Foreign Ministers of Canada, Statement on the Situation in the West of Libya (05.04.19), https://www.diplomatie.gouv.fr/en/french-foreign-policy/french-g7-presidency/events/article/g7-foreignministers-statement-on-the-situation-in-the-west-of-libya-05-04-19 (accessed 23 March 2021).

80 Vienna Convention on the Law of Treaties (1969), Art. 53.

81 International Covenant on Civil and Political Rights (1966), 999 UNTS 171, Art. 15(2).

82 Vienna Convention on the Law of Treaties (1969), Art. 53.

83 McCorquodale (2006), pp. 255, 257-261.
} 
the only ones with law-making authority. ${ }^{84}$ Other forms of international law making, such as that carried out by certain international institutions, ultimately stem from the authority of states and reflect the delegation of their law-making authority. ${ }^{85}$ For now at least, the state remains 'the basic unit in the world of public international law'.86

However, there is an aversion to the notion that the interest of the 'international community as a whole' should be limited to that of the international community of states. ${ }^{87}$ This would certainly appear at first glance to limit the scope and potential of the concept. Such an interpretation would indeed appear to be scarcely reconcilable with much of the usage of the phrase 'interest of the international community' by international courts and indeed by states themselves. ${ }^{88}$ This concern is, however, an unnecessary one. It is premised upon a misunderstanding of the commonality of common interests. As noted above, the community interest is a common interest. It is not, therefore, the sum total of the individual interests of the 'holders' of that interest. Instead, as explained above, it reflects values ${ }^{89}$ or concerns ${ }^{90}$ that transcend their individual interests. The international community in this sense is not a collection of legal actors, but an idea. It is a legal fiction to which we impute interests, in very much the same way as we impute interests to the socio-legal construct of 'the public'. In this way, the 'international community' finds definition (at least for these purposes) in the international community interest, and not the other way around.

Thus, the international community interest may be understood as a common interest that is imputed to the socio-legal construct of the 'international community'. These two aspects - the interest and the community-are intricately connected and intertwined within the notion of community interest. The impact that this concept has had on the development of international law has been transformative. While in some ways this change has been slow and subtle, with certain developments taking decades to emerge as doctrine, the evolution of key elements of the international legal order as a result of the community interest is striking. This is particularly so

\footnotetext{
${ }^{84}$ With the notable exception of international organisations, although this can still be explaining in terms of state sovereignty as international organisations only enjoy this status or quality because they are inter-state institutions; they gain their subjecthood by being essentially groupings of states: Reparation for Injuries Suffered in the Service of the United Nations, Advisory Opinion, ICJ Reports 1949, p. 174, para. 185.

85 See e.g. Charter of the United Nations (1945), 1 UNTS XVI, Chapter VII for the law-making powers of the UN Security Council.

86 Simma and Paulus (1998), p. 273.

87 See e.g. Kritsiotis (2002), pp. 973 et seq.; Villalpando (2005), p. 20.

88 See e.g. Barcelona Traction (n. 4), paras. 33-34; Whaling in the Antarctic (Australia v. Japan: New Zealand Intervening), Merits, Judgment, ICJ Reports 2014, p. 226, para. 69; Legality of the Threat or Use of Nuclear Weapons, Advisory Opinion, ICJ Reports 1996, p. 226, para. 62; United States-Import Prohibition of Certain Shrimp and Shrimp Products, 12 October 1998, WT/DS58/AB/R, para. 122; Responsibilities and Obligations of States with Respect to Activities in the Area, Advisory Opinion, ITLOS Reports 2011, p. 10, para. 180.

89 De Wet (2006); Reservations to the Convention on Genocide, Advisory Opinion, ICJ Reports 1951, p. 15, p. 23.

90 E.g. the concept of the common concern of mankind in international environmental law: Convention on Biological Diversity (1992), 1760 UNTS 79, preamble.
} 
when viewed in relation to the question of the public nature of the international legal order.

\subsection{Community Interest and Publicness}

The legal incorporation of the community interest has introduced many new elements to the international legal landscape. Overall, its effects have been transformative. States are no longer free to enter into treaties the terms of which would be in conflict with peremptory norms, such as the prohibition of torture. ${ }^{91}$ Rather than providing a forum merely for the settlement of disputes between individual state interests, international adjudication now covers questions relating to common and community interests brought by uninjured states. ${ }^{92}$ From human rights to environmental protection and beyond, modern international law regulates conduct even within states own domestic sphere or in international areas, rather than being limited to the classical relations between states. ${ }^{93}$

When one looks at the impact of community interest on the international legal order, it becomes apparent that its effects can be closely linked to a publicness narrative. The following sections will demonstrate how the establishment and development of the community interest have introduced and strengthened many of the elements of publicness discussed above in the international legal order.

\subsubsection{Community}

In the domestic setting, the 'community' that forms the public is easily established. There is already a well-recognised social and legal framework, made up of elements such as shared language, national identity, and citizenship. Despite this, there is no reason that the notion of 'public' should necessarily be attached to the form of social organizing of the nation state. If publicness is something inherent in an organized legal-political community (as opposed to a 'state of nature' or 'anarchic condition'), ${ }^{94}$ then it would seem bizarre were the concept to be artificially attached to just one form of such a community. In European Union law we have a good example of how concepts of publicness, including constitutionalism, can transcend states. ${ }^{95}$

\footnotetext{
91 Questions Relating to the Obligation to Prosecute or Extradite (Belgium v. Senegal), Judgment, ICJ Reports 2012, p. 422, para. 99.

92 See e.g. Whaling in the Antarctic (n. 88).

93 Amongst many possible examples, see: Convention on Biological Diversity (1992); Antarctic Treaty (1959), 402 UNTS 71; Convention on the Conservation of Antarctic Marine Living Resources (1980), 1329 UNTS 47; International Covenant on Civil and Political Rights (1966); International Covenant on Economic, Social and Cultural Rights (1966), 993 UNTS 3; Convention on Psychotropic Substances (1971), 1019 UNTS 175; International Convention against Doping in Sport (2005), 2419 UNTS 201.

94 Mulholland (1993), p. 116.

95 Weiss (2011). Of course, constitutionalism can also occur at the substate level, especially in federalist states.
} 
Public law is about 'communal life'"96; it relates to "communities and not fragmentary or individual interests' ${ }^{97}$ rather than the construct of the nation state.

Given the dis-embedded nature of the international community, ${ }^{98}$ it has been questioned whether this is a sufficient basis for a true political community. The traditional social elements are lacking; there is a distinct absence of social cohesion (or 'political dimension' or 'social embeddedness'). ${ }^{99}$ The international community lacks the 'social fabric' that is common to domestic systems ${ }^{100}$; it lacks a 'consciousness of community' 101 or 'community sentiment 102 akin to that which is supposed to exist within national polities. This has led some commentators to cast doubt on the idea that there exists a true international community at all, and certainly one that could be understood as a public - that if such a community exists at all, it is 'symbolic' ${ }^{103}$; 'pure illusion'. ${ }^{104}$ It is indeed doubtful that there is or even could be a degree of social cohesion equivalent to that at the domestic level, despite references to concepts like the 'human family' ${ }^{105}$ or 'global citizens' ${ }^{106}$

From a legal perspective, however, it is simply unnecessary to establish the existence of a social community when we can look instead to a community rooted in law. As has been noted above, the community interest has been integrated into the international legal system and the secondary rules of international law. The existence of such a community is codified through legal elements such as obligations erga omnes and peremptory norms. Quite distinct from the question of whether there is an international 'social' community, this legal framework is evidence of a legal community of interest that could amount to an international 'public'. ${ }^{107}$ The international community is a legal fiction, a social construct-just like the notion of the public. The legal protection of its interest incorporates this fiction into the structures of international law, creating the basis for a public legal order at this level. As such, the international community - the international public, so to speak-is a community of interest, premised upon the shared international community interest.

\subsubsection{Universality}

Universality is a difficult concept to apply to international law in the same way as in the domestic sphere due to the absence of clear doctrinal and geographical borders. Rather than focusing on these traditional boundaries, Simma defines 'a universalist approach to international law' as one that incorporates 'the conviction that

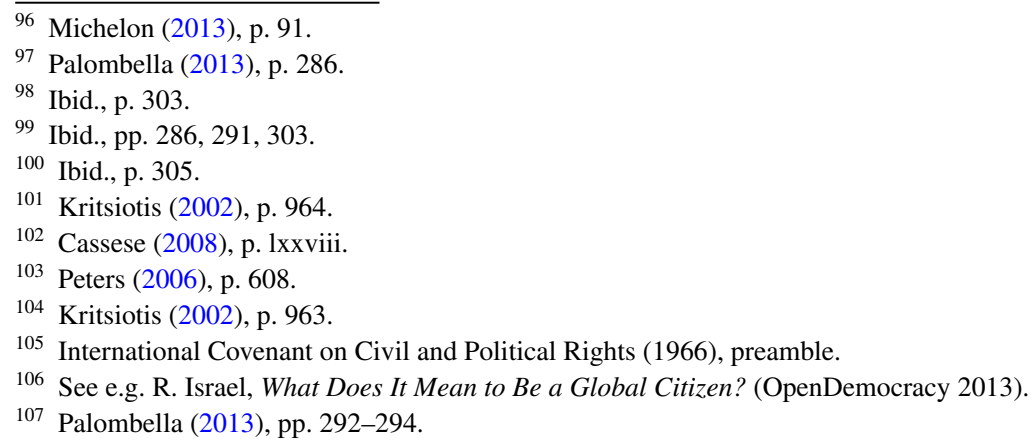


it is possible, desirable, indeed urgently necessary [...] to establish a public order on a global scale, a common legal order for mankind as a whole'. ${ }^{108}$ This relates to the idea of a shared, common interest, expressed through law; it goes to a commonality of purpose. ${ }^{109}$ It relates to whether the community in question 'knows of values other than the sovereign identities of its individual members-whether the "community" becomes more than a mere collection of its parts'. ${ }^{110}$ To the extent that community interest provides this, it therefore brings to international law an idea of universality or 'universalism' 111 that was previously absent.

It does so, first, by incorporating the notion of a shared system of values. This idea is particularly visible in the constitutionalist narrative. De Wet builds her theory of constitutionalism around what she calls the 'international value system', or 'a core value system common to all communities and embedded in a variety of legal structures for its enforcement'. ${ }^{112}$ This core value system is expressed, at least in part, through the operation of 'public interest norms' ${ }^{113}$ including peremptory norms and obligations erga omnes, both of which are referred to as 'exemplary reflections of the international value system'. ${ }^{114}$ Both are widely understood (if not 'universally accepted, ${ }^{115}$ ) as being based upon a 'strong ethical underpinning, ${ }^{116}$ related to the higher values of the international community. ${ }^{117}$ The prohibition of torture is a good example. ${ }^{118}$ The idea is that there are certain core ethical convictions-in these examples, a shared abhorrence of such conduct—expressed in law, that bind all states together into a universal understanding.

The commonality of the community interest extends beyond values to the concept of 'global public goods'. ${ }^{119}$ Although a relatively recent addition to international legal theory, the concept of public goods is not a new one. ${ }^{120}$ Such goods possess two main qualities: non-rivalry (in the sense that 'one person can use [the good] without diminishing its availability to others') and non-excludability (no one can be prevented from enjoyment of the good). ${ }^{121}$ Key examples in international law include the protection of the global environment ${ }^{122}$ and the maintenance of international peace and security. ${ }^{123}$ Translating these concepts to the international plane,

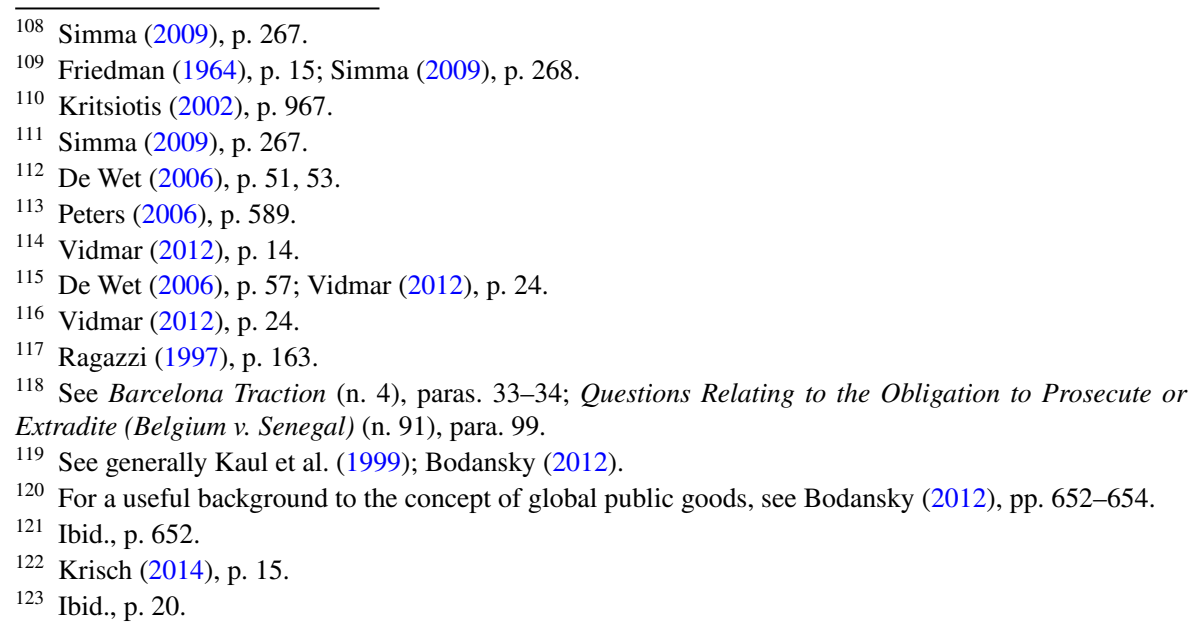


it is easy to see how the interest in protecting such goods transcends the individual interests of states. Bodansky has expressly conceptualised obligations erga omnes 'in terms of global public goods: if an obligation primarily relates to the provision of a global public good or the prohibition of a global public bad, then the obligation protects a "collective" or "common" interest and should be owed to the international community of states as a whole'. ${ }^{124}$

\subsubsection{Hierarchy}

The traditional, 'Westphalian' picture of the international legal landscape is flat: there are no normative hierarchies, and all sovereign actors are equal. ${ }^{125}$ However, the community interest has introduced a multitude of hierarchies, both normative and institutional, into international law.

To begin with, the community interest underlies various forms of normative differentiation. Certain categories of norms have developed whose legal effect is differentiated in accordance with the interest of the international community-or the international public interest. Such norms are referred to by some as 'public interest norms ${ }^{126}$ and play an important role in modern constitutionalist literature. ${ }^{127}$ The first and most obvious example of such 'public interest norms' ${ }^{128}$ is jus cogens, or peremptory norms. ${ }^{129}$ These norms enjoy a higher normative status, ostensibly due to the interest of the international community in their compliance and validity. ${ }^{130}$ Thus, a treaty rule in conflict with a rule of jus cogens will be considered invalid. ${ }^{131}$ These can essentially be seen as a public-law-style limitation on the freedom of states to enter into agreements (freedom of contract). ${ }^{132}$

Obligations erga omnes can also be seen as a further example of normative differentiation on the basis of community interest, despite the fact that they are not technically speaking hierarchically superior norms. ${ }^{133}$ Beyond these, the introduction of Articles 40 and 41 in the ILC's Articles on State responsibility create a differentiated form of responsibility that results in the imposition of additional legal consequences for 'serious breaches of peremptory norms' ${ }^{134}$ While this represents

\footnotetext{
$\overline{124}$ Bodansky (2012), pp. 653-654.

125 Shelton (2014), p. 138; Osiander (2011), pp. 77-89.

126 Peters (2006), p. 589.

127 See e.g. ibid., p. 598; De Wet (2006).

128 Peters (2006), p. 589.

129 Vienna Convention on the Law of Treaties (1969), Art. 53.

130 Villalpando (2005), p. 84.

131 Vienna Convention on the Law of Treaties (1969), Art. 53. See also International Law Commission, Third Report on Peremptory Norms of General International Law (Jus Cogens) by Special Rapporteur Dire Tladi (2018) at p. 11.

132 Benedek et al. (2014), p. 223.

133 Villalpando (2005), p. 84; C. Eggett and S. Thin, 'Clarification and Conflation: Obligations Erga Omnes in the Chagos Opinion', EJIL: Talk!, https://www.ejiltalk.org/clarification-and-conflation-oblig ations-erga-omnes-in-the-chagos-opinion/ (accessed 22 March 2021).

134 ILC, Draft Articles on Responsibility of States for Internationally Wrongful Acts, with Commentaries, Arts. 40 and 41.
} 
a departure (at least in name) from the notion of 'state crime' in the ILC's infamous 1996 Draft Article 19, ${ }^{135}$ this differentiation still points to the kind of normative hierarchy and differentiation that is inherent in publicness.

Hierarchies between actors can also be seen in relation to international organisations and institutions. The most obvious example is the United Nations (UN). Through its Chapter VII powers, the UN Security Council (UNSC) can make decisions that are legally binding upon member states once it has determined that there exists 'any threat to the peace, breach of the peace, or act of aggression'. and in order to 'maintain or restore international peace and security'. ${ }^{136}$ In practice, the concept of 'threat to international peace and security' has been interpreted widely, and has notably been applied by the UNSC in situations that do not relate to 'international conflict' in the strict sense (i.e. between states), but internal issues that would traditionally have been within the exclusive domain of the state, such as gross human rights violations. ${ }^{137}$ The UNSC thus has the power to limit and control the actions of states (and groups and individuals) ${ }^{138}$ without their immediate consent, 'for the benefit of the international community as a whole'. ${ }^{139}$ This resembles a form of public authority.

Some commentators have argued that an international court can also exercise 'international public authority'. ${ }^{140}$ The traditional understanding of the role of international courts is 'as mere instruments of dispute settlement whose activities are justified by the consent of the states that create them and in whose name they decide'. ${ }^{141}$ Here, thus, the 'dominant notions stem from private law'. ${ }^{142}$ Von Bogdandy and Venzke emphasise the power taken by certain courts to determine the extent of their own competence. ${ }^{143}$ They present the ICJ in particular as being capable of exercising 'judicial control' over other actors in the international legal order, including the UNSC. ${ }^{144}$ As such, they view courts as 'organs of the international community' 145 which 'can control and legitimize not only international institutions, but also public authority on the international level'. ${ }^{146}$

\footnotetext{
135 ILC, Draft Articles on the Responsibility of States for Internationally Wrongful Acts (1996), Art. 19.

136 Charter of the United Nations (1945), Art. 39.

137 E.g. UNSC Resolutions 1267 (15 October 1999), 1970 (26 February 2011), 1973 (17 March 2011);

De Wet (2006).

138 Vidmar (2012), p. 119.

139 Ibid., p. 119.

140 Von Bogdandy and Venzke (2014), p. 17.

141 Ibid., p. 1.

142 Krisch (2012), p. 980.

143 Von Bogdandy and Venzke (2014), p. 16.

144 Ibid., p. 16; Krisch (2012), p. 980.

145 Von Bogdandy and Venzke (2014), p. 3.

146 Ibid., p. 15.
} 


\subsubsection{Objectivity}

Finally, the legal framework around the community interest has been a catalyst for the objectivisation of international legal obligation and responsibility. Under traditional, bilateralist conceptions of international law, an obligation operates exclusively as between two subjects, where one subject owes to the other the performance of certain conduct. This obligation is mirrored by the 'subjective right' of the other subject (to whom the obligation is owed) to the performance of that conduct. ${ }^{147}$ This model of obligation is essentially subjective in that the conduct is not owed in the absolute, urbi et orbi [...] but only in relation to the particular State'. ${ }^{148}$ This translates into a subjective or relative relationship of responsibility, where the responsibility of the wrongdoing state exists only in relation to the injured state, i.e. the state to which the obligation is owed (and thus the state whose subjective right to the performance of the specified conduct was violated). The injured state may choose not to invoke the responsibility of the wrongdoing state (or otherwise be prevented from doing so, such as where an injured state loses the right to invoke responsibility ${ }^{149}$ ), in which case the responsibility of the wrongdoing state will remain uninvoked. ${ }^{150}$

This model is increasingly being challenged by community interest-related developments on two fronts. On the one hand, the focus of law-making on common and community interests such as environmental protection has resulted in a dramatic increase in structurally non-bilateral (or non-bilateralisable ${ }^{151}$ ) obligations in international law. ${ }^{152}$ These obligations cannot be broken down into such bilateral relationships ${ }^{153}$; they are not owed directly between two parties but rather are rather objective standards of conduct the are binding on the state. As such, the breach of a non-bilateral obligation does not translate into a subjective relationship of responsibility as there is no injured state. Instead, some form of decentralised enforcement (as e.g., through the operation of obligations erga omnes) is necessary.

Let us take, for example, the Convention on Biological Diversity. ${ }^{154}$ Many obligations within this Convention may indeed be breached in a bilateral manner. A state may, for example, refuse to share with one or several other states information relevant to the conservation and sustainable use of biological diversity in violation of

\footnotetext{
147 R. Ago, Second Report on State Responsibility, ILC Yearbook 1970, vol. 2, pp. 192-193: 'The correlation between a legal obligation on the one hand and a subjective right on the other admits of no exception'. See also De Hoogh (1995), pp 18-19.

148 Simma (1994), p. 230. See also Paulus (2011), p. 122: 'in a bilateralist system, legal norms do not define an objective standard against which to hold individual state behaviour to account, but rather a relative standard giving another party the right to demand compliance in case of breach'.

149 ILC, Draft Articles on Responsibility of States for Internationally Wrongful Acts, with Commentaries, Art. 45.

150 Simma (1994), pp. 230-231.

151 Sicilianos (2002), p. 1133.

152 Ibid., p. 1135-1136; Sivakumaran (2009), p. 150.

153 See e.g. G.G. Fitzmaurice, Third Report on the Law of Treaties, ILC Yearbook 1958, vol. II, pp. 27-28, Art. 19. See also Sachariew (1988), p. 281; Tams (2005), p. 56.

154 Convention on Biological Diversity (1992).
} 
Article $17 .{ }^{155}$ This would create a bilateral relationship of responsibility between the state refusing to share such information and each of the states with whom it refuses to share, along the lines of the bilateral model discussed above. However, what if the same state failed to protect an area of internationally significant biodiversity on its own territory, in violation of the provisions under Article $8 ?^{156}$ These obligations relate to the state's internal organisation of its affairs and no other state is directly affected. There is no injured state and thus no bilateral relationship of responsibility; instead, the responsibility is objective in nature.

In addition to such structurally non-bilateral obligations, the recognition of the importance to the international community of some bilateral(isable) obligations has had a significant impact. The category of erga omnes is not reserved to those obligations that would not result in an injured state when breached. The obligation not to commit aggression, for example, would clearly result in direct injury to at least one state who would then be granted powers of invocation of responsibility under the traditional schema. ${ }^{157}$ However, following Barcelona Traction and the ILC's Articles on State Responsibility, any state can invoke responsibility for such an act, reflecting the recognition that the wrongfulness of this conduct is not premised solely on the injury to the victim state, but also in relation to the international community as a whole. ${ }^{158}$

As such, it is apparent that the broader effects of the community interest have served to integrate many elements of publicness into the international legal order. The international community is key to this. The other three elements-universality, hierarchy, and objectivity - are all linked to this central interest-based community that lies at the heart of what it means to be public. This is not to say that bilateralist or private-law-type structures no longer have a role in international law-on the contrary, they remain an essential part thereof. Nonetheless, these developments point towards a different paradigm of international law, one in which there are elements of the international legal system that can be understood as reflecting publicness.

Thus, it may be concluded that the introduction and operation of the international community interest underlie a transition in international law from a private to a more public legal order. It remains to be seen what the implications of this development and this characterisation may be, both for the present state of international law and for its future development. Having determined that we may refer to the international legal system as 'public', it must next be asked what the consequences of this nomenclature are. Is the label of 'public' purely descriptive, or does it have broader implications? In other words, what is the point of publicness?

\footnotetext{
155 Ibid., Art. 17(1).

156 Ibid., Art. 8.

157 Barcelona Traction (n. 4), para. 34; ILC, Draft Articles on Responsibility of States for Internationally Wrongful Acts, with Commentaries, Art. 42.

158 Barcelona Traction (n. 4), paras. 33-34; ILC, Draft Articles on Responsibility of States for Internationally Wrongful Acts, with Commentaries, Art. 48.
} 


\section{The Point of Publicness}

Stepping beyond the purely theoretical, there are a number of possible ways in which the classification of public law or a public legal order may have implications in and of itself. Publicness is clearly valuable as an explanatory tool: the elaboration and application of a notion of publicness is useful to understand and situate the changing shape and nature of international law. It may, however, go further. This section reflects on some of the possible implications of the public characterisation.

The notion of publicness is wrapped up with numerous political, legal, philosophical, and even moral ideas as to the nature and quality of public law. Public forms of law are often associated with certain norms and standards-'public law principles', including 'accountability, transparency, hierarchy, as well as rationality, proportionality, the rule of law, and fundamental rights.' 159

Some have argued that in a public legal order, these principles have an impact on the validity of law. Kingsbury and Donaldson write that

The publicness approach as a whole goes further than a descriptive approach: it rests on the notion that certain public law principles, and a more abstract quality of publicness, are inherent in law itself and, to this extent at least, explicitly incorporates criteria which, if not straightforwardly moral in content, at least have a strong normative dimension. ${ }^{160}$

They go on to suggest that such principles or criteria could 'form part of practices, if not a singular rule, of recognition'. ${ }^{161}$ To claim that such principles are already incorporated in the law pertaining to international legal sources is rather difficult to maintain, however. With the exception of the jus cogens limitation on the formation of rules contrary to certain fundamental community interests, there is little evidence that such criteria have made their way into doctrine.

Beyond validity, however, is the question of legitimacy. Seeing international law through a public law lens makes the lacunae stand out more sharply-the absence of a centralised, compulsory judicial system; the relative lack of accountability; the absence of transparency and the limited nature of the fora that we have for discussion and law-making. If international legal structures are increasingly built around the idea of community or public interest rather than exclusively around individual state interests, this new structure should be judged by different criteria and standards. As such, the label of publicness provides a strong platform from which to launch critical and normative analyses of the existing international legal order.

Publicness gives us a means to theorise these issues. We can now begin to link international law to domestic ideas of political accountability that originate in political science. ${ }^{162}$ In this way, the concept of publicness serves to frame the

\footnotetext{
159 Schwöbel (2012), p. 1112. See also Kingsbury and Donaldson (2011a), pp. 84, 86; Peters (2006), pp. 583, 600; Goldmann (2016), p. 64.

160 Kingsbury and Donaldson (2011a), p. 86.

161 Ibid., p. 88.

162 Krisch (2012), p. 977.
} 
international legal order in a different manner. ${ }^{163}$ We are increasingly seeing public law principles, such as transparency, ${ }^{164}$ democracy, ${ }^{165}$ and the rule of law ${ }^{166}$ being used as standards by which to measure the legitimacy of international law rules, structures, and institutions. ${ }^{167}$ There is a strong focus on the use of such principles and structures as means to 'tame politics and power' at the international level, ${ }^{168}$ particularly in the context of the perceived erosion of the divide between domestic and international spheres. ${ }^{169}$ Publicness provides us with a normative framework and vocabulary through which to argue for the kind of developments that would improve legitimacy and accountability. ${ }^{170}$ Understanding these structures and narratives through the concept of community interest helps to bring them together and consolidate them into a broader, more complete picture of what an international public legal order could be.

Finally, understanding the international legal system as a public legal order provides us with a model for the development and understanding of key legal elements within international law. It may indeed be that the limited expression of publicness as it currently exists in international law could be 'something of a by-way on the path to developing a theoretical basis for the dense and intrusive rules and institutions and governance processes serving multiple interests and constituencies that more and more characterise international law'. ${ }^{171}$ These developments raise important questions for scholars and lawyers. Community interest sits somewhat uncomfortably beside traditional bilateralist structures and norms. As discussed above, ${ }^{172}$ bilateralist ideas relating to the nature of obligation and responsibility are incompatible with a community interest approach. Similarly, the beginnings of a development of institutional and normative hierarchies challenge many traditional legal precepts. The public model offers a new perspective on these problems and a means of finding answers to the questions that arise therefrom. It can provide us a means of drawing lines within an international legal order that contains both public and private elements.

\section{Conclusion}

The concept of community interest is a fundamental part of the shift towards publicness in international law. This article began by exploring different theories of the distinction between public and private in law before drawing out four key elements

\footnotetext{
163 Peters (2006), p. 605.

164 Notably Bianchi and Peters (2013); Donaldson (2017).

165 See e.g. Charlesworth (2015); Burchill (2006).

166 E.g. Keith (2015); De Baere et al. (2016).

167 See Schwöbel (2012), p. 1123; Peters (2006), p. 583.

168 Krisch (2012), p. 981.

169 Ibid., p. 978; Peters (2006), p. 580.

170 Peters (2006), p. 602.

171 Kingsbury and Donaldson (2011a), p. 80.

172 See Sect. 3.2.4.
} 
of publicness that could be applied to the international legal order: community, universality, hierarchy, and objectivity. Turning to international law, it demonstrated that the impact of community interest may be seen as introducing and strengthening each and every one of these elements within the international legal system. The recognition of the community interest is central to the definition of an international public, or community to which the notion of public attaches. The incorporation of community interest protection into differentiated normative structures has created normative hierarchies, while certain community interest actors have begun to exercise a form of public authority previously unheard of in international law. Community interest has changed the fundamental nature of international legal obligation and responsibility, whereby both now operate in an objective rather than subjective manner. Community interest thus lies beneath a fundamental evolution of the international legal system, from private to public.

Establishing the public nature of the international legal order and the role of the community interest in its development serves several purposes. As an explanatory tool, it can be used to describe and situate developments in the international legal system. While it may be going too far to identify international legal rules of validity with public law principles like transparency and accountability, these principles can inform a more in-depth understanding of legitimacy at the international level. Beyond this, the publicness model can help us predict the ways in which international law may develop in the future, and how, and can help us to fill in the gaps in a legal system where much remains uncertain.

Community interest has slowly but surely transformed the international legal order. We have stepped from public international law into the beginnings of an international public law. This publicness, properly understood and applied to the international sphere, is more than just a change in linguistics. It is a toolbox for the new international legal order.

Open Access This article is licensed under a Creative Commons Attribution 4.0 International License, which permits use, sharing, adaptation, distribution and reproduction in any medium or format, as long as you give appropriate credit to the original author(s) and the source, provide a link to the Creative Commons licence, and indicate if changes were made. The images or other third party material in this article are included in the article's Creative Commons licence, unless indicated otherwise in a credit line to the material. If material is not included in the article's Creative Commons licence and your intended use is not permitted by statutory regulation or exceeds the permitted use, you will need to obtain permission directly from the copyright holder. To view a copy of this licence, visit http://creativecommons.org/licen ses/by/4.0/.

\section{References}

Bamforth N (1999) The application of the Human Rights Act 1998 to public authorities and private bodies. Cambridge Law J 58:159-170

Benedek W et al (2014) Conclusions: the common interest in international law-perspectives for an undervalued concept. In: Benedek W et al (eds) The common interest in international law. Intersentia, Cambridge, pp 219-227 
Benvenisti E (2008) The conception of international law as a legal system. German Yearb Int Law 50:393-405

Besson S (2018) Community interests in international law: whose interests are they and how should we best identify them? In: Benvenisti E, Nolte G (eds) Community interests across international law. Oxford University Press, Oxford, pp 36-49

Bianchi A, Peters A (eds) (2013) Transparency in international law. Cambridge University Press, Cambridge UK

Bodansky D (2012) What's in a concept? Global public goods, international law and legitimacy. Eur J Int Law 23:651-668

Burchill R (ed) (2006) Democracy and international law. Ashgate, Farnham

Cassese A (2008) The human dimension of international law: selected papers of Antonio Cassese. Oxford University Press, Oxford

Cassinelli C (1958) Some reflections on the concept of the public interest. Ethics 69:48-61

Charlesworth H (2015) Democracy and international law. Recueil des Cours 371:43-152

Ciongaru E (2014) Various historical considerations regarding the public law-private law dichotomy. Perspect Bus Law J 3:111-115

De Baere G, Chane A-L, Wouters J (2016) International courts as keepers of the rule of law: achievements, challenges, and opportunities. N Y Univ J Int Law Politics 48:715-794

De Hoogh A (1995) Obligations erga omnes and international crimes: a theoretical inquiry into the implementation and enforcement of the international responsibility of states. Dissertation, Katholieke Universiteit Nijmegen

De Wet E (2006) The international constitutional order. Int Comp Law Q 55:51-76

Demichel A, Laumière P (1974) Le droit public. PUF, Paris

Donaldson M (2017) The survival of the secret treaty: publicity, secrecy, and legality in the international order. Am J Int Law 111:575-627

Donaldson M, Kingsbury B (2013) The global governance of public law. In: Mac Amhlaigh C, Michelon C, Walker N (eds) After public law. Oxford University Press, Oxford, pp 264-285

Dupuy P-M (2005) Some reflections on contemporary international law and the appeal to universal values: a response to Martti Koskenniemi. Eur J Int Law 16:131-137

Friedman W (1964) The changing structure of international law. Columbia University Press, New York

Gaja G (2013) The protection of general interests in the international community. Recueil des Cours 364:9-185

Goldmann M (2016) A matter of perspective: global governance and the distinction between public and private authority (and not law). Glob Const 5:48-84

Gowlland-Debbas V (1996) Judicial insights into fundamental values and interests of the international community. In: Muller AS, Raic D, Thuransky JM (eds) The International Court of Justice: its future role after 50 years. Martinus Nijhoff, Leiden, pp 327-366

Hart HLA (2012) The concept of law. Oxford University Press, Oxford

Held V (1970) The public interest and private interests. Basic Books, New York

Holland TE (1916) The elements of jurisprudence. Oxford University Press, Oxford

Kaul I, Grunberg I, Stern M (eds) (1999) Global public goods: international cooperation in the 21st century. Oxford University Press, Oxford

Keith KJ (2015) The international rule of law. Leiden J Int Law 28:403-417

Kelsen H (1949) General theory of law and state. Routledge, London

Kelsen H (2009) Pure theory of law. The Lawbook Exchange, New Jersey

King SM, Chilton BS, Roberts GE (2010) Reflections on defining the public interest. Admin Soc 41:954-978

Kingsbury B, Donaldson M (2011a) From bilateralism to publicness in international law. In: Fastenrath U et al (eds) From bilateralism to community interest: essays in honour of Bruno Simma. Oxford University Press, Oxford, pp 79-89

Kingsbury B, Donaldson M (2011b) Global administrative law Max Planck encyclopedia of public international law. Oxford University Press, Oxford

Knox JH (2008) Horizontal human rights law. Am J Int Law 102:1-47

Krisch N (2012) Global governance as public authority: an introduction. Int J Const Law 10:976-987

Krisch N (2014) The decay of consent: international law in an age of global public goods. Am J Int Law 108: $1-40$

Kritsiotis D (2002) Imagining the international community. Eur J Int Law 13:961-992

Loughlin M (1992) Public law and political theory. Oxford University Press, Oxford

Loughlin M (2004) The idea of public law. Oxford University Press, Oxford 
Loughlin M (2013) The nature of public law. In: Mac Amhlaigh C, Michelon C, Walker N (eds) After public law. Oxford University Press, Oxford, pp 11-24

Mates P, Barton M (2011) Public versus private interest-can the boundaries be legally defined? Czech Yearb Int Law 2:172-189

McCorquodale R (2006) International community and state sovereignty: an uneasy symbiotic relationship. In: Warbrick C, Tierney S (eds) Towards an 'international community'? The sovereignty of states and the sovereignty of international law. BIICL, London, pp 241-265

Ménard M (2010) Circumstances precluding wrongfulness in the ILC Articles on State Responsibility: compliance with peremptory norms. In: Crawford $\mathrm{J}$ et al (eds) The law of international responsibility. Oxford University Press, Oxford, pp 449-453

Michelon C (2013) The public, the private, and the law. In: Mac Amhlaigh C, Michelon C, Walker N (eds) After public law. Oxford University Press, Oxford, pp 83-100

Mulholland LA (1993) The difference between private and public law. Jahrbuch für Recht und Ethik 1:113-158

Oliver D (2004) Functions of a public nature under the Human Rights Act. Public Law, 329-351

Osiander A (2011) The states system of Europe, 1640-1990: peacemaking and the conditions of international stability. Oxford University Press, Oxford

Palombella G (2013) The (re-)constitution of the public in a global arena. In: Mac Amhlaigh C, Michelon C, Walker N (eds) After public law. Oxford University Press, Oxford, pp 286-309

Paulus A (2011) Reciprocity revisited. In: Fastenrath U et al (eds) From bilateralism to community interest: essays in honour of Judge Bruno Simma. Oxford University Press, Oxford, pp 113-137

Peters A (2006) Compensatory constitutionalism: the function and potential of fundamental international norms and structures. Leiden J Int Law 19:579-610

Ragazzi M (1997) The concept of obligations erga omnes. Oxford University Press, Oxford

Sachariew K (1988) State responsibility for multilateral treaty violations: identifying the 'injured state' and its legal status. Neth Int Law Rev 35:273-289

Schwöbel CEJ (2012) Whither the private in global governance? Int J Const Law 10:1106-1133

Shelton D (2009) Form, function, and the powers of international courts. Chic J Int Law 9:537-572

Shelton D (2014) International law and 'relative normativity.' In: Evans MD (ed) International law. Oxford University Press, Oxford, pp 137-165

Sicilianos L-A (2002) The classification of obligations and the multilateral dimension of the relations of international responsibility. Eur J Int Law 13:1127-1145

Simma B (1994) From bilateralism to community interest in international law. Recueil des Cours 250:217-384

Simma B (2009) Universality of international law from the perspective of a practitioner. Eur J Int Law 20:265-297

Simma B, Paulus A (1998) The 'international community': facing the challenge of globalization. Eur J Int Law 9:266-277

Sivakumaran S (2009) Impact on the structure of international obligations. In: Kamminga MT, Scheinin M (eds) The impact of human rights law on general international law. Oxford University Press, Oxford, pp $133-150$

Sorauf FJ (1957) The public interest reconsidered. J Politics 19:616-639

Tams C (2005) Enforcing obligations erga omnes in international law. Cambridge University Press, Cambridge

Tierney S (2013) The nation as 'the public': the resilient functionalism of public law. In: Mac Amhlaigh C, Michelon C, Walker N (eds) After public law. Oxford University Press, Oxford, pp 151-167

Verdross A (1964) Völkerrecht. Springer, Vienna

Vidmar J (2012) Norm conflicts and hierarchy in international law: towards a vertical international legal system? In: Vidmar J, De Wet E (eds) Hierarchy in international law: the place of human rights. Oxford University Press, Oxford, pp 13-41

Vidmar J (2014) Protecting the community interest in a state centric legal system: the UN Charter and certain norms of 'special standing'. In: Benedek W et al (eds) The common interest in international law. Intersentia, Cambridge, pp 109-126

Villalpando S (2005) L'émergence de la communauté internationale dans la responsabilité des Etats. Graduate Institute Publications, Geneva

Villalpando S (2010) The legal dimension of the international community: how community interests are protected in international law. Eur J Int Law 21:387-419 
Von Bogdandy A, Venzke I (2014) In whose name? A public law theory of international adjudication. Oxford University Press, Oxford

Von Bogdandy A, Peters A, Less S (2016) The publicness of public international law seen through Schmitt's concept of the political-a contribution to building public law theory. Max Planck Institute for Comparative Public Law and International Law, Heidelberg

Weill A, Terré F (1979) Droit civil: introduction générale. Dalloz, Paris

Weiss F (2011) Sketching 'community interest' in EU law. In: Fastenrath U et al (eds) From bilateralism to community interests: essays in honour of Bruno Simma. Oxford University Press, Oxford, pp 406-416

Willoughby WW (1924) The fundamental concepts of public law. Fred B Rothman \& Co, New York

Zarecor WD (1959) The public interest and political theory. Ethics 69:277-280

Publisher's Note Springer Nature remains neutral with regard to jurisdictional claims in published maps and institutional affiliations. 